\title{
Anti-Privatisation Debates, Opaque Rules and 'Privatised' Water Services Provision: Some Lessons from Indonesia
}

\author{
Mohamad Mova Al 'Afghani
}

\begin{abstract}
Anti-privatisation debates dominate Indonesia's contemporary water discourse. This has culminated in attempts at invalidating the Water Law through a Judicial Review. Finally rejected by the Constitutional Court, the law remains in place, although polarised debate remains and prevents greater regulation across the sector. The polarised debate leads to hesitations in regulating private sector participation (PSP). As a result, there is a major lack of regulation of PSP in the water sector. This article examines two contexts Jakarta, where a concession takes place and Bogor, where the service is run entirely by a publicly owned company. Customer rights, such as the right to be connected, to enjoy certain service levels, to compensation, to financial aid, to redress mechanisms, including the right to participation and transparency, barely exist in Jakarta but are adequately guaranteed in Bogor.
\end{abstract}

\section{Anti-privatisation debates \\ The Indonesian Water Law was controversial even before enactment in 2004. During parliamentary debate, members of the House of Representatives from various political affiliations expressed their concern through minderheidsnota, ${ }^{1}$ although the Law was eventually unanimously passed by the parliament.}

A total of 19 articles on the Water Law were submitted for Judicial Review. Of all the articles, only four of them (Articles 9, 40, 45 and 46) are in fact directly related to 'privatisation' both in terms of water resources and services. The remainder deal with the application of economic principles in water resources management. During this process, United Nations documents such as the Resolution for the International Drinking Water Supply and Sanitation Decade (United Nations 1980), Agenda 21 (United Nations 1993) and the General Comment 15 (United Nations GESCR 2003) were referred to, as well as the Dublin Principles, which emphasised water as 'an economic good'. Agenda $21^{2}$ - rather than New Delhi - was perceived as the antithesis to Dublin and emerged as one of the instruments cited during the Review process.

Expert testimony outlined that the principal differences between Dublin and Agenda 21 was that the former emphasis was on water as an economic good while the latter described water both as an economic and social good. With two dissenting opinions, the petitions to revoke the Law were eventually rejected by the Court, declaring the Law to be 'Conditionally Constitutional'. ${ }^{3}$

However, the anti-privatisation debate has not subsided. Activists have sought the possibility of a further Judicial Review and are collecting evidence to reinforce their arguments. Some have requested that the implementing regulation of the Water Law on water services the Government Regulation 16 Year 2005 - on Drinking Water Provision System be nullified. ${ }^{4}$ In this polarised atmosphere there have been complaints within the Ministry of Public Works that opposition has impeded the enactment of a Draft Government Regulation on Water Use Rights, which - if issued - would be the most

IDS Bulletin Volume 43 Number 2 March 2012 (c) 2012 The Author. IDS Bulletin (c) 2012 Institute of Development Studies Published by Blackwell Publishing Ltd, 9600 Garsington Road, Oxford OX4 2DQ, UK and 350 Main Street, Malden, MA 02148, USA 
important implementing regulation of the Water Law. $^{5}$ As one author puts it:

... a small handful of non-state actors and activist organizations are not pluralistic by definition... Discussions have not helped expand discourses toward a reconciliatory realm of promoting a plural public policy debate (Regmi 2010).

We examine further these polarised debates through an assessment of the experience of two cities - Jakarta and Bogor.

\section{Opaque rules on Private Sector Participation}

Indonesian water services are regulated primarily by two rules: the Water Law $7 / 2004^{6}$ and the Government Regulation 16 Year 2005 (GR-16). ${ }^{7}$ Out of 100 articles in Law 7/2004, only one paragraph specifically regulates Private Sector Participation (PSP): paragraph 4 of Article 40. Central government has also issued numerous guidelines in the form of 'Ministerial Regulations', but they are not binding on regional governments. Water services are the responsibility of local government.

The single paragraph in the Water Law that is supposed to regulate PSP does not provide clarity as to the extent and format of PSP allowed by the Water Law. Paragraph 4 states 'Cooperatives, privately-owned business enterprises and [members of the] society may participate in the undertaking of the development of [the] drinking water provision system' (author's italics). In order to obtain coherent interpretation, one needs to pay attention to the preceding paragraph (paragraph 3) which states: 'State Owned Enterprises and Regionally Owned Enterprises are the undertakers ${ }^{8}$ of [the] drinking water provision system' (author's italics). The phrase 'merupakan penyelenggara' in paragraph 4 of Article 40 has often been translated as ' $\ldots$ will be the organizers of $\ldots$ and '.. shall carry out the development of ...'. However, since 'penyelenggara' is a noun, whereas 'merupakan' is a statement of being, the author regards that '.. are the undertakers of ...' is the most appropriate English translation.

The rationale in separating the provision regulating the private sector in paragraph 4 with provision on State Owned Enterprises in paragraph 3 must be that the drafters of the law intended their roles to be differentiated. The author concludes that the drafters must have intended for State Owned Enterprises to be the main actor in the provision of drinking water while not entirely forbidding PSP. If PSP is to be regulated in great detail, there is a higher risk of invalidation by the Constitutional Court, as shown on the Judicial Review of the Electricity Law. Hence, the drafters left the clause on PSP vague and subsumed it in the same clause regulating cooperatives and 'other' members of the community.

Paragraph 4 of Article 64 of GR-16 stipulates that any involvement of the cooperatives or privately owned business enterprise should be done through a proper procurement procedure, as stipulated under prevailing laws and regulations while the fifth paragraph stipulates that following such procurement, the cooperatives or privately owned business enterprise shall 'enter into agreement' with the government.

\section{3 'Neglected' PSPs}

\subsection{A brief history of Jakarta's 'concession'}

There is a vast literature addressing the problems of the Jakarta water concession (see Kooy 2008; Iwanami and Nickson 2008; Bakker 2006, 2007). In late 1991, a combination of the World Bank and Japanese aid provided a loan to PAM Jaya (Jakarta's Regional Waterworks Company) in order to repair and expand its infrastructure (Harsono 2005). Soon after the loan was provided, the World Bank approached the Indonesian government to allow private sector participation in Jakarta's water system. In 1995, the coverage of PAM Jaya was only 45 per cent, 30 per cent of which received intermittent supply (Jensen 2005). In 1996, unaccounted for water was more than 55 per cent. Due to these problems, more investment was needed in order to expand coverage (Lanti 2006). The government thought that inviting private sector input would lower tariffs and bring investment to the city's ailing water infrastructure (Braadbaart 2007). RWE Thames Water acted first (Harsono 2005) by forming an alliance with Sigit Harjojudanto, the son of the ruling President Soeharto (ibid.) in exchange for a 20 per cent ownership of the project company. This move was later followed by Suez Lyonnaise by forming an alliance with the Salim Group, who were also close to former President Soeharto. ${ }^{9}$

Without any public tender and to the disappointment of the World Bank (Braadbaart 
2007), Soeharto finally agreed to privatise Jakarta's water supply in 1995 and subsequently ordered the Ministry of Public Works at that time to divide Jakarta into two service regions bordering the Giliwung River. One part was to be given to his son Harjojudanto and Thames and the other half was to be provided to the Salim group and Suez. The negotiation process would take two years.

According to Braadbaart, the contract was signed with the most important contractual risks borne by PAM Jaya: (1) currency risk; (2) gradual tariff increase and projected sales; and (3) bulk water supplies. One of the most fatal blows to the contractual design was linking the security of these risks to private sector performance. In the event that PAM Jaya failed to secure the risks, the private sector would not be obligated to materialise its commitments. ${ }^{10}$

Agreement on the original Jakarta 'concession' bypassed any official procurement rules (Harsono 2003). Many have discussed that the contract contained flaws with unbalanced distribution of risks and built-in disincentives for both the private sectors and the PAM Jaya to extend the network to the poor (Bakker 2006, 2007). What is rarely discussed is the legal framework surrounding the 'concession' contract.

As discussed in the previous section, both Water Law 7/2004 and the GR-16, although vague in terms of ownership and regulatory model, to $a$ limited extent regulate service levels, ${ }^{11}$ customer service, and good governance issues. ${ }^{12}$ Both the regulator and the private sector denied, however, that Water Law and GR-16 were applicable to the Jakarta Cooperation Contract. ${ }^{13}$ Indeed, the Water Law does not contain any provision obligating that licences issued prior to its enactment be adjusted accordingly. This has been criticised at the Water Law's Judicial Review. Without the new rules applicable to the concession contract, the Jakarta PSP is left with two regional by-laws regulating water services.

However, water service in Jakarta is regulated by an 18-year-old rule, Regional By-Law 11/1993 ('By-Law 11'). Enacted in 1993, four years before the 'concession' contract was entered in 1997, this has never been reformed or amended since and is still in force today. Most rules in water services would contain the rights and obligation of customers. Some of the rights guaranteed are the right to be connected, the right to enjoy a certain level of service (see Hendry 2008), the right to customer service, the right to be compensated, the right to financial aid, the right to redress, including the right to 'good governance' processes such as the right to participation and transparency (Al 'Afghani 2009) of the regulatory process. None of these rights are guaranteed by By-Law 11 and some are even denied.

The only 'rights' provided by By-Law 11 are the 'right' to ask for examination of a water meter, ${ }^{14}$ to complain against inaccurate water metering (although it will not suspend their obligation to pay their monthly water tariffs) ${ }^{15}$ and the right to make an 'objection' to the governor over penalties for water theft levied by PAM Jaya's director. Even this right to object is 'binding'"16 and no other recourse is provided by By-Law 11 although access to Court is in theory available.

The absence of customer rights, participation, transparency mechanisms and the power vested on PAM Jaya to arbitrarily disconnect customers for non-payment appears to challenge the International Covenant on Economic, Social and Cultural Rights (ICESCR) to which Indonesia is a party. ${ }^{17}$

3.2 Comparing Jakarta's regional by-laws (concession) with Bogor's regional by-law (publicly owned)

In order to obtain a clearer picture of the 'neglect' of PSP in the water sector, this section contrasts the regulatory framework in water services between Jakarta and Bogor. Bogor is a municipality $60 \mathrm{~km}$ south of Jakarta with a population of 750,000 (compared to Jakarta's 10 million) and its water services are run by a publicly owned company.

Bogor's water services by-law was modified in 1996 and 2006. The 2006 amendment is particularly distinctive as it contains many guarantees on service levels and customer rights. The regional autonomy, which delegates the management of drinking water services to local government, might have been the driver for these reforms. This can be seen from a tendency in several other regions to conduct utilities reform after the autonomy was introduced in $2001 .^{18}$

The comparison between Jakarta's 1992/3 by-laws with Bogor's by-law, comes under five categories: 
duty to connect, service level/customer service, customer rights, redress mechanisms and tariff/bill components. These are discussed below. ${ }^{19}$

In Jakarta's by-laws, there is a duty to serve a connection request from the industrial, residential or tourist sectors ${ }^{20}$ imposed on the regional-owned waterworks company. However, there is no duty directly imposed on the private sector to connect customers. In Bogor, there is a general duty 'to serve' water services for its residents and a specific duty to extend the network to regions with groundwater of inadequate quality. ${ }^{21}$

In terms of service levels, the Jakarta by-laws refer to the Ministerial Decree on drinking water quality; ${ }^{22}$ but in practice, changes to the Decree are not automatically applicable. Due to the concession, changes to water quality regulation must be negotiated with the private sector. On the other hand, any changes to water quality regulation are directly applicable in Bogor. The Bogor regional by-law also contains provisions regulating service disruptions, the general obligation for the regional waterworks company to supply water of a certain quality, continuity and quantity (except in the event of force majeure) and a 24-hour customer service call centre and mailbox. ${ }^{23}$

In terms of customer rights, the only 'right' available in the Jakarta regional by-law is the 'right' to object to PAM Jaya about an incorrect water meter, ${ }^{24}$ the 'right' to object against imposition of penalties by the Governor and the 'right' to request an examination of the water meter. Even these are not directly formulated as rights. The word used is 'may', i.e. 'dapat mengajukan keberatan'('may' propose objection). On the other hand, the Bogor regional by-law contains provisions guaranteeing several rights, including to: (i) obtain results on the examination of water quality, accuracy of metering device, calculation of water bill; (ii) obtain an explanation on the agreed terms when submitting new connection requests; (iii) obtain information on the structure and amount of tariff; and (iv) receive a 50 per cent discount of the monthly fee if the water supply is disconnected on three consecutive days without prior notice. ${ }^{25}$

\section{Conclusion}

Drafters of the Water Law refrained from creating detailed provisions and chose to regulate PSP only vaguely. Out of 100 articles in the Water Law, only one paragraph is dedicated specifically to regulating PSP in water services. This move was criticised by one of the Judges' Dissenting Opinion as a 'disguised privatisation'.

At the local level where PSP occurs, such as in Jakarta, regulatory reforms have stopped at two 18-year-old regional by-laws, which have never been amended since enactment. Hence, the Jakarta 'concession' took place without sufficient back-up from a wider regulatory framework. In the present by-laws, there are no adequate guarantees on the utilities' duty to provide connections, service level/customer service, customer rights, redress mechanism or tariff/bills. In Bogor, by contrast, where water is publicly owned, these are effectively regulated.

The anti-privatisation debate has not been successful in democratising water services; instead, because of the government's reluctance to regulate PSP, this has resulted in water services being negotiated bilaterally through contractual means between government and the private sector, and away from public scrutiny.

For PSP to be better regulated in the future, Indonesia needs to move to a consensus at a national level. As a starting point, this requires anti-privatisation debates to become progressively depolarised. 


\section{Notes}

1 Minderheidsnota is a minor note from the legislator. The content of the minderheidsnota is not binding as law but could be used to supplement interpretation and to provide insight into the history of the formation of a law.

2 United Nations (1993). See para 18.8: 'Integrated water resources management is based on the perception of water as an integral part of the ecosystem, a natural resource and a social and economic good, whose quantity and quality determine the nature of its utilization'.

3 Judicial Review of the Law No 7 Year 2004 regarding Water Resources, Judgment of 13 July 2005, No 058-059-060-063/PUUII/2004, Constitutional Court of the Republic of Indonesia, 2005.

4 Pemerintah Harus Koreksi Privatisasi Sumber Daya Air [The Government Must Correct Water Resources Privatisation], Suara Pembaruan, Jakarta, 2005.

5 Personal communications with a consultant from the Ministry of Public Works, April 2009.

6 Undang Undang No 7 Tahun 2004 Tentang Sumber Daya Air [Law No 7 Year 2004 on Water Resources], Indonesia.

7 Peraturan Pemerintah No 16 Tahun 2005 Tentang Pengembangan Sistem Penyediaan Air Minum [Government Regulation 16 Year 2005 on Drinking Water Provision System], Indonesia.

8 Undang Undang No 7 Tahun 2004 Tentang Sumber Daya Air [Fn 8: Law No 7 Year 2004 on Water Resources], Indonesia.

9 'Access to politics is essential. The water business is always political, Bernard Lafrogne, a Suez representative in Jakarta, told me' (Harsono 2005).

10 In one interview, a member of the Jakarta Water Sector Regulatory Body (JWSRB) demonstrated the stance of the private sector and its lawyers that the contract is not measured by performance. Hence, there is an inherent lack of incentive for the private sector to achieve service level targets in the contractual design (Jakarta, December 2009).

11 Article 68, GR-16.

12 Article 68, GR-16.

13 Various field interviews with the regulatory body, the private sector and NGOs in Jakarta, January-February 2011.
14 Article 20.1, By-Law 11 (Jakarta).

15 Article 19.1 and 2, By-Law 11 (Jakarta).

16 Article 28.3, By-Law 11 (Jakarta).

17 International Covenant on Economic, Social and Cultural Rights New York, 16 December 1966, United Nations, Treaty Series, Vol. 993, p. 3; depositary notification C.N.781.2001. See also United Nations CESCR (2003) and de Albuquerque (2010).

18 See regional by-laws enacted in various regions, for example (2003) Peraturan Daerah Kabupaten Takalar No 15 Tahun 2003 Tentang Perusahaan Daerah Air Minum, (2004) Peraturan Daerah Kabupaten Sragen No 8 Tahun 2004 Tentang Perusahaan Daerah Air Minum Kabupaten Sragen, (2006) Peraturan Daerah Provinsi Kalimantan Barat No 2 Tahun 2006 Tentang Pendirian Perusahaan Daerah Air Minum Provinsi Kalimantan Barat, (2011) Peraturan Daerah Kendal No 13 Tahun 2011, (2011) Peraturan Daerah Kabupaten Maros No 4 Tahun 2011 Tentang Perusahaan Daerah Air Minum [(2003) Regional By-Law of Takalar Regency No 15 Year 2003 on Regional Drinking Water Company; (2004) Regional By-Law of Sragen Regency No 8 Year 2004 on Sragen Regional Drinking Water Company; (2006) Regional By-Law of West Kalimantan Province No 2 Year 2006 on the Establishment of West Kalimantan Drinking Water Company; (2011) Regional By-Law of Kendal Regency No 13 Year 2011; (2011) Regional By-Law of Maros Regency No 4 Year 2011 on Regional Drinking Water Company].

19 Service standards including drinking water quality standard, duties to extend network and customer service standard are among the common features of a water services law. See Hendry (2008).

20 By-Law 13 (Jakarta).

21 Indonesia Peraturan Daerah Kota Bogor Nomor 5 Tahun 2006 Tentang Pelayanan Air Minum Perusahaan Daerah Air Minum Tirta Pakuan Kota Bogor. Article 3 hereinafter 'By-Law 5 (Bogor)'.

22 Article 19.1, By-Law 13 (Jakarta).

23 Article 20, By-Law 5 (Bogor).

24 Article 15, By-Law 11 (Jakarta).

25 Article 20, By-Law 5 (Bogor). 


\section{References}

Al 'Afghani, M.M. (2009) 'The Transparency Agenda in Water Utilities Regulation and the Role of Freedom of Information: England and Jakarta Case Studies', Journal of Water Law 20.2-3: 129-43

Bakker, K. (2007) 'Trickle Down? Private Sector Participation and the Pro-Poor Water Supply Debate in Jakarta, Indonesia', Geoforum 38.5: 855-68

Bakker, K. (2006) 'Conflicts over Water Supply in Jakarta, Indonesia', in B. Barraqué and E. Vlachos (eds), Urban Water Conflicts, an Analysis of the Origins and Nature of Water-related Unrest and Conflicts in the Urban Context, Working series SC-2006/WS/19, Paris: United Nations Educational, Scientific and Cultural Organization (UNESCO)

Braadbaart, O. (2007) 'Privatizing Water. The Jakarta Concession and the Limits of Contract', in P. Boomgaard (ed.), A World of Water. Rain, Rivers and Seas in Southeast Asian Histories, Leiden: KITLV Press: 297-319

de Albuquerque, C. (2010) Report of the Independent Expert on the Issue of Human Rights Obligations Related to Access to Safe Drinking Water and Sanitation, A/HRC/15/31, Geneva: United Nations

Harsono, A. (2005) 'When Water and Political Power Intersect', Nieman Reports, www.nieman.harvard.edu/reportsitem.aspx?id $=101044$ (accessed 20 December 2011)

Harsono, A. (2003) 'Water and Politics in the Fall of Suharto', Center for Public Integrity, www.icij.org (accessed 20 December 2011)
Hendry, S.M. (2008) 'An Analytical Framework for Reform of National Water Law', DPhil thesis, University of Dundee

Iwanami, M. and Nickson, A. (2008) 'Assessing the Regulatory Model for Water Supply in Jakarta', Public Administration and Development 28.4: 291-300

Jensen, O. (2005) 'Troubled Partnerships: Problems and Coping Strategies in Jakarta's Water Concessions', 4th Conference on Applied Infrastructure Research, Berlin

Kooy, M.É. (2008) 'Relations of Power, Networks of Water: Governing Urban Waters, Spaces, and Populations in (Post) Colonial Jakarta', PhD, University of British Columbia

Lanti, A. (2006) 'A Regulatory Approach to the Jakarta Water Supply Concession Contracts', International Journal of Water Resources Development 22.2: 255-76

Regmi, A. (2010) 'Users and Disappearing Water', Jakarta Post, 22 April

United Nations (1993) Agenda 21: The United Nations Programme of Action from Rio: Earth Summit, Geneva: United Nations

United Nations (1980) UNGA Resolution 35/18 on the Proclamation of the International Drinking Water Supply and Sanitation Decade, A/35/367

United Nations GESGR (Committee on Economic Social and Cultural Rights) (2003) General Comment No 15 (2002), The Right to Water (arts. 11 and 12 of the International Covenant on Economic, Social and Gultural Rights), Geneva: United Nations 